\title{
16. 矩形空に传る眚光率の簡單なる求めち及其應用に就て（其1）*
}

\author{
正員朴村莘一郎 ${ }^{1}$
}

\section{1. 問題の範園}

本文は畫光照明のうちで天空から室內に入射する兆束による直射照度に關する問題を取扱ふ もので，室內に於ける摭散照度の方は全部考へてない，室內の或點の照度はこれを屋外の其時

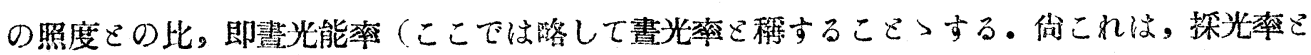
いふ樣な字句にした方が理解し易い樣に思はれる。）で示すここが最も便利であるから，此書 光率を最も簡單に求められる樣に工夫してみた。倘本文に示してあるのは，垂直なる䄳形恣の

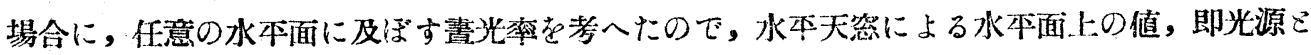
本行面の場合はまば計算してるない。

\section{2. 求 क 万}

室內の水本面上の或點の照度は，其點から笞を通じて紫み得る天空面積の値から求的るか,

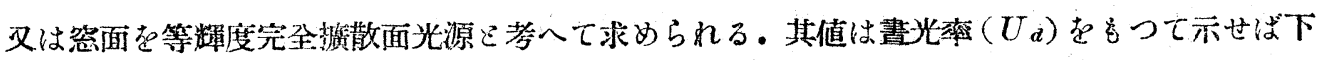
の如き形である。

$$
U_{\mathrm{d}}=\frac{1}{2 \pi}\left[\tan ^{-1} \frac{b}{x}-\frac{x}{\sqrt{x^{2}+a^{2}}} \tan ^{-1} \frac{b}{\sqrt{x^{2}+a^{2}}}\right] \cdots
$$

但し此算式は矩形面光源の一隅から垂直方向 $x$ なる距離にある點の畵光率を示すすので，從 つて一般の場合としては， $U_{d}=U_{1}-U_{2}-U_{3}+U_{4}$ なる手數を要する. 即ち上式から 4 つ場 合を求むて，その代數和を以つて答をするものである。此主つの手數を 1 つの式にすれば。次 の形になる。

$$
U_{d}=\frac{1}{2 \pi}\left[\frac{x}{A}\left\{-\tan ^{-1} \frac{C}{A}+\tan ^{-1} \frac{D}{A}\right\}+\frac{x}{B}\left\{\tan ^{-1} \frac{C}{B}-\tan ^{-1} \frac{D}{B}\right\}\right]
$$

何れにしても上式の計算は簡單な樣であるが，宝內に於ける多くの點の照度ら見出す場合に 一夕計算することは，中々手數苍要し，甚げ賽用的ではないこれに對する簡便法として，(1) 式の各項は $\frac{1}{2} \frac{1}{\sqrt{1+h^{2}}} \tan ^{-1} \frac{b^{\prime}}{\sqrt{1+h^{2}}}$ なるるのを含导から，これを $h 及 b^{\prime} の$ 各值について計算し

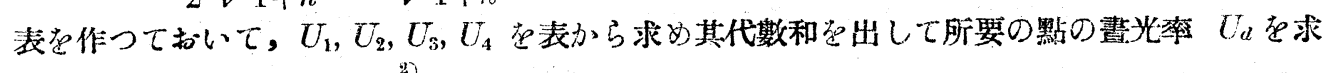

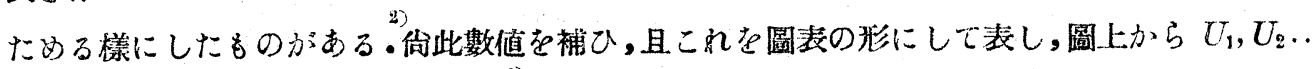

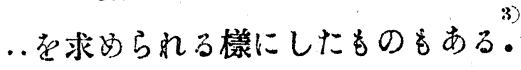

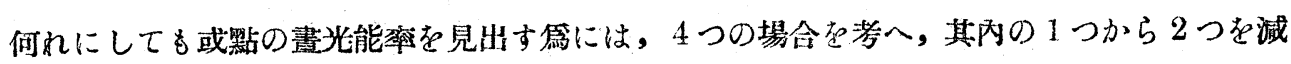
じ，1つを加へねばならない，又全然計算に依らすして，天空の各部分の輝度を圆上に示し，

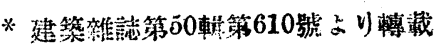

1) 早稻田大學筡師

2) 照明工學ポケットブック, p. 328.

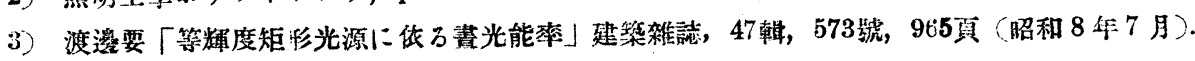


室內の或點から登を通して望み得る天空面積から和る樣にした工夫も 2,3 の例がある・此方法 にしてる相當の手數を要するものである。

箠者は此等に對して更に求め易く，且精雄なる値を短時間に知り得る樣に次の如き方法を考 へてみた。

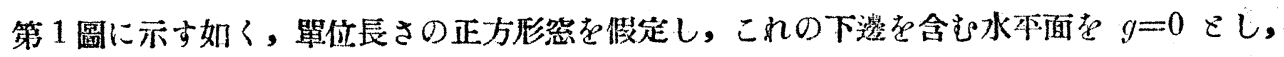
順次單位長さだけ下つた水本面を $g=1,2, \ldots$ として示す。笞から左右に單位長さだけの距離

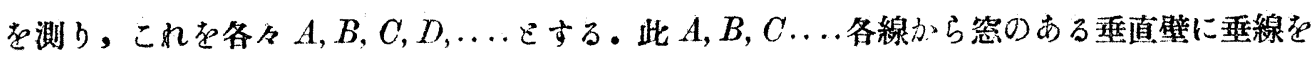

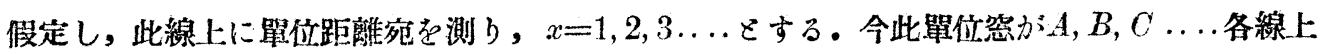
の $x$ 及 $g$ に及ぼす所の畫光率を前式から計算して表又は圖にして示しておけば，任意の形の矩

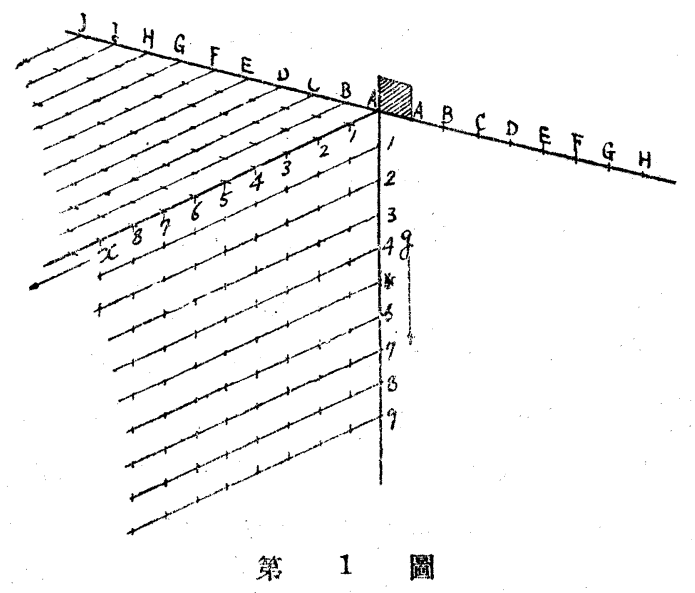
形空が室內の任缶の點に及ぼす書光率 は，簡單に等せ算を行へば求められるこ とになる。即ち恣の幅及高さと求むる水 平面迄の距離，gの間に適當なる整數（最 大公約數）を見出し，これを單位をすれ ばよい，又多くの窓のある場合は，窓ど 㝕の間の距離も前 3 つの數に加へて, 其 等の間に最大公約數をとればよい。

然万已きは求むる水本面上の各點に於 る鷕光率は，單位長さに對する $x$ 及 $g, A$, $B, C$. 線の何れに相賞するかる見れば，

表又は圖から淔に空內の單位正方形部分の畫光率が得られるから，形及數に應じて，其點に及

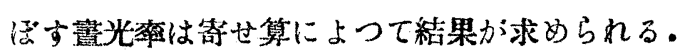

各點の畫光率を知れば，本面上に等照度線（畫光率にて示されたもの）を描くことは容易で

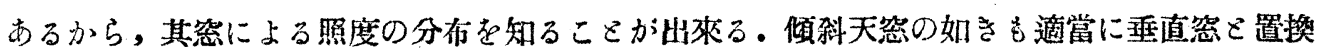
へて此表走利用することか出來る。

又設計せんをする空內の畫光率の必要量を各部分について，豫め定めるなれば，表或に圖か ら登の大さ，形を決定することが容易に出來る。

\section{3. 其他の問題}

劣縱に長い葖と，横に長い窓の入射光束を計算した。それから本均害光率を出してみたが，

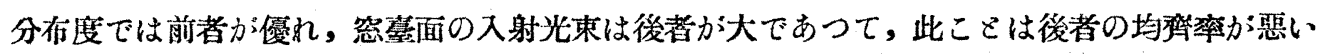

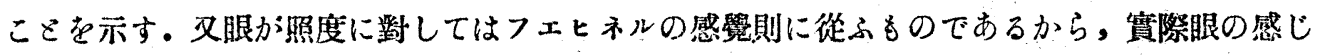
ろ割合を 2,3 の例について，對數目盛りの圆に表してみた。 